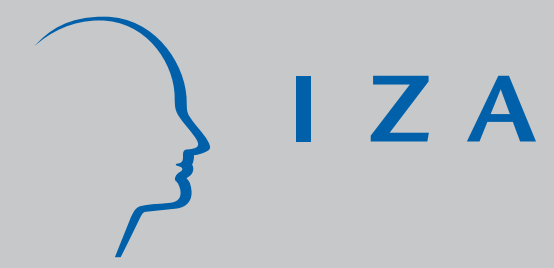

IZA DP No. 1238

The Linguistic and Economic Adjustment of Soviet Jewish Immigrants in the United States, 2000: A Preliminary Report

Barry R. Chiswick

Michael Wenz

August 2004 


\title{
The Linguistic and Economic Adjustment of Soviet Jewish Immigrants in the United States, 2000: A Preliminary Report
}

\author{
Barry R. Chiswick \\ University of Illinois at Chicago \\ and IZA Bonn \\ Michael Wenz \\ University of Illinois at Chicago
}
Discussion Paper No. 1238
August 2004

\author{
IZA \\ P.O. Box 7240 \\ 53072 Bonn \\ Germany \\ Phone: +49-228-3894-0 \\ Fax: +49-228-3894-180 \\ Email: iza@iza.org
}

\begin{abstract}
Any opinions expressed here are those of the author(s) and not those of the institute. Research disseminated by IZA may include views on policy, but the institute itself takes no institutional policy positions.

The Institute for the Study of Labor (IZA) in Bonn is a local and virtual international research center and a place of communication between science, politics and business. IZA is an independent nonprofit company supported by Deutsche Post World Net. The center is associated with the University of Bonn and offers a stimulating research environment through its research networks, research support, and visitors and doctoral programs. IZA engages in (i) original and internationally competitive research in all fields of labor economics, (ii) development of policy concepts, and (iii) dissemination of research results and concepts to the interested public.
\end{abstract}

IZA Discussion Papers often represent preliminary work and are circulated to encourage discussion. Citation of such a paper should account for its provisional character. A revised version may be available directly from the author. 


\section{ABSTRACT \\ The Linguistic and Economic Adjustment of Soviet Jewish Immigrants in the United States, 2000: A Preliminary Report}

This paper is an analysis of the English-language proficiency and labor market earnings of Soviet Jewish immigrants to the United States from 1965 to 2000, using the 2000 Census of Population. Comparisons are made to similar analyses using the 1980 and 1990 Censuses. A consistent finding is that recently arrived Soviet Jewish immigrants have lower levels of English proficiency and earnings than other immigrants, other variables being the same. However, they have a steeper improvement in both proficiency and earnings with duration in the United States and the differences from the other European immigrants disappear after a few years. The Soviet Jewish immigrants have both a higher level of schooling and a larger effect of schooling on earnings than other immigrants, even other European immigrants.

The lower initial English proficiency and earnings, the steeper improvement with duration and the rapid attainment of parity is consistent with the refugee nature of their migration. That the same pattern exists across three censuses suggests that it is a refugee assimilation process, and not a decline in the unmeasured dimensions of the earnings potential of recent cohorts of Soviet Jewish immigrants. The larger effect of schooling on earnings among Soviet Jewish immigrants is similar to the larger effect of schooling on earnings among Jews born in the United States. Soviet Jewish immigrants to the United States since 1965 appear to have made a very successful linguistic and labor market adjustment.

JEL Classification: J6, J31, J24

Keywords: earnings, language proficiency, immigrants, Jews, Soviet Union

Corresponding author:

Barry R. Chiswick

Department of Economics (M/C 144)

University of Illinois at Chicago

601 South Morgan Street (Room 2103 UH)

Chicago, IL 60607-7121

USA

Email: brchis@uic.edu

\footnotetext{
* An earlier version of this paper was presented at the International Conference in Honor of the Retirement of Professor Mordechai Altshuler, Hebrew University, Jerusalem, December, 28-30, 2003. Chiswick acknowledges the research support of the Institute of Government and Public Affairs, University of Illinois.
} 


\section{Introduction}

The purpose of this paper is to continue a line of research on the linguistic and labor market adaptation of Russian or Soviet Jewish immigrants in the United States in the post-1965 period. Linguistic adaptation, that is, the acquisition of English language proficiency, is important for many reasons, including increasing access to U.S. schooling and job training and success in the labor market, whether measured by employment or earnings. Moreover, it is important for acquiring U.S. citizenship and thereby expanding job opportunities and increasing political influence. Labor market success is an important element in a family's economic wellbeing and determines current consumption as well as having an influence on marital formation and stability, fertility, and parental investments in the human capital of their children.

This study constitutes an extension of earlier work by one of the authors on turn-of-the$20^{\text {th }}$ century Russian Jewish immigrants, as well as work on Soviet Jewry in the late $20^{\text {th }}$ century using the 1980 and 1990 Censuses of Population of the United States (Chiswick, 1993, 1997). The data under study in this paper are from the 2000 Census of the United States, Public Use Microdata Sample (Census, 2000). ${ }^{1} \quad$ A random sample of one percent of the population is studied.

\section{Migration from the Former Soviet Union}

With the impending and actual collapse of the Soviet Union in 1989 a massive exodus began of the Jewish population. Between 1989 and 2003, 1.6 million Jews and their non-Jewish

\footnotetext{
${ }^{1}$ In principle, data from the recently released National Jewish Population Survey (NJPS) 2000/01 can be used to study the economic status of Soviet Jewish immigrants. The NJPS 2000/01, however, provides a relatively smaller sample of Soviet Jews and does not permit a comparison with other immigrant groups. An analysis of Soviet Jews in the NJPS compared to other Jews is a separate project.
} 
relatives left the former Soviet Union, 200,000 each in 1990 and 1991 alone, with the numbers declining thereafter to only 35,000 in 2003 (Tolts 2004). The primary destination was, of course, Israel which received over 950,000 or 61 percent of the emigrants. The emigration data suggest that about 315,000 Jews and their non-Jewish relatives left the FSU for the United States, or about 20 percent of the emigrants. Another 160,000 (10 percent) went to Germany, with the remainder settling in a wide range of destinations.

From the start of official record keeping in the United States in 1820, to the present, approximately 4.0 million people are recorded as having immigrated (permanent resident aliens) to the United States from Russia or the former Soviet Union (Table 1). There have been immigrants to the U.S. from the Russian Empire/Soviet Union in every decade since the start of record keeping in the 1820's. The peak decade was 1901-1910 when 1.6 million immigrants were recorded, followed by 1911-1920 when 0.9 million were recorded (Table 2). But immigration from the Soviet Union declined sharply thereafter, with less than 600 recorded in the 1940 's, rising to nearly 700 in the 1950 's, 2,500 in the 1960 's, 39,000 in the 1970 's, 58,000 in the 1980 's, and nearly 463,000 in the 1990 's (1991-2000), for a total of 560,000 over the period 1865-2000. Because of these trends, the analysis is limited to those who first came to the United States to stay in 1965 or later.

A large proportion entered as refugees or asylees (Table 2). The 2000 Census suggests that there were about 700,000 people living in the United States who were born in the former Soviet Union. They may have entered with permanent resident alien visas or under other visas and provisions of immigration law. 


\section{Who is a Soviet Jew?}

The first step in an analysis of "Soviet Jews" in the United States is to define each of the two terms. For the purpose of this study, persons born in any of the constituent republics of the Former Soviet Union are referred to as "Soviet immigrants". Thus, the analysis is not to be limited to those born in "Russia" loosely defined or in the Russian Republic.

Defining Jews is more problematic. The Census of the United States, unlike censuses in some other Diaspora countries, such as Canada and Australia, has never asked religion. In the 2000 census microdata file anyone who responds to the question on ethnic ancestry by revealing a religion is assigned the same ancestry code (998) as all other religious responses. Any response indicating Jewishness, even if the response is "secular Jew", is combined with and thereby masked with other religious responses.

Yet, clearly, not all respondents from the former Soviet Union are Jews. Those who report an Armenian ancestry or who report that they speak Armenian at home are not likely to be Jewish. Thus, for a first approximation for the purposes of this paper, persons born in the former Soviet Union who do not report an Armenian ancestry or Armenian as a language spoken at home are the subject of this analysis and for simplicity of exposition are considered Soviet Jews. ${ }^{2}$

This study is limited to the analysis of adult (age 25 to 64) males. For younger and older persons school enrollment and retirement decisions have a major impact on labor supply, and

\footnotetext{
${ }^{2}$ The ethnic origins (ancestry) of the adult (age 25 to 64) males born in the Soviet Union who immigrated in 1965 or later were 41 percent Russian, 20 percent Ukrainian, 11 percent Armenian, 10 percent response indicating a religion, 6 percent no ancestry reported and 13 percent other responses. By languages spoken in the home, only English was reported by 4 percent, Russian 72 percent, Armenian 9 percent, Ukrainian 7 percent, Yiddish 0.2 percent and all other languages 8 percent. There was little variation in the reported ancestry or language by sub-period of immigration. See Appendix Tables A1-A2.
} 
choice of jobs, and hence earnings. Similarly, the labor market attachment of women is strongly influenced by marital status and child care responsibilities. Analyses of these labor supply decisions are beyond the scope of this study.

\section{Descriptive Statistics}

Table 3 reports the means and standard deviations of selected variables relevant for the analysis. The Soviet immigrants are less proficient in English than either European or Asian immigrants. Among the Soviet immigrants 74 percent reported that they speak only English at home or speak another language but speak English very well or well. Twenty-six percent reported that they spoke English not well or not at all. In contrast, 88 percent of the European immigrants and 82 percent of the Asian immigrants satisfy this definition of English proficiency. Among those with earnings, the adult men from the former Soviet Union (Soviet Jews) earned nearly $\$ 38,800$ in 1999 , considerably less than the earnings of other European $(\$ 50,400)$ and Asian $(\$ 42,700)$ immigrants, but substantially more than Latin American immigrants $(\$ 23,000)$.

The Soviet immigrants have some characteristics that would enhance their language proficiency and earnings potential, but other characteristics that would have a negative impact. Their educational level is very high, an average of 14.9 years of schooling, far greater than even the 14.1 years among Asian immigrants, the 13.6 years among other European immigrants, or the 11.5 years among all (including Soviet) immigrants. On the other hand, the Soviet immigrants had a very short period of residence in the U.S. In 2000, among those who immigrated in 1965 or later, 72 percent of the Soviet Jews had been in the U.S. 10 or fewer years, in contrast to 37 percent overall. 
The two measures of employment tell a similar story. Among those who worked, the weeks worked in 1999 were lower for Soviet (46.5 weeks) than for European (47.7 weeks) or Asian (46.9 weeks) immigrants, although greater than among Latin American immigrants (45.2 weeks). Among those in the labor force in the reference week, the last week in March 2000, 3.6 percent of the Soviet immigrants were unemployed, in contrast to 2.4 percent and 2.7 percent for European and Asian immigrants, respectively.

Table 4 provides greater detail on the English language proficiency of immigrants. Immigrants from the former Soviet Union are least likely to speak only English at home (4.5 percent compared to 13.4 percent for all immigrants) and are more likely than European and Asian immigrants to report that they speak English "not well" or "not at all" (26.8 percent). Only the Latin American immigrants have a greater proportion (42.8 percent) in these two least proficient categories.

\section{Methodology for Statistical Analysis}

A multivariate statistical analysis (ordinary least squares regression analysis, OLS) is used to compare Soviet Jewish immigrants to other immigrants, when other measured variables are held constant. That is, controlling for factors such as age, schooling, marital status, and duration in the United States, do Soviet Jews differ in English language proficiency and earnings from other immigrants?

The statistical analysis uses the adult (age 25 to 64 ) male respondents in the 2000 Census Public Use Microdata Sample, one percent sample of the population, as the unit of observation. The two dependent variables under study are proficiency in English and labor market earnings. 
The language variable is a dichotomous variable defined to equal unity for those who speak only English at home or if they speak another language they speak English "very well" or "well". It is zero for those who speak English "not well" or "not at all". The earnings variable is the natural logarithm of annual earnings in 1999, where earnings are the sum of wage, salary and self-employment income. Those who reported zero earnings or did not work in 1999 are deleted from the analysis. Those who reported earnings of less than $\$ 100$, including the negligible number reporting negative earnings, were assigned a value of $\$ 100$ since the natural logarithm is not defined for zero or negative values. ${ }^{3}$

The econometric model for the analysis of language proficiency is based on earlier research that specifies three fundamental concepts (Chiswick and Miller 1998). These are exposure to the destination language, efficiency in destination language acquisition, and economic incentives for learning the destination language. In the empirical application the measurable variables reflecting these conceptual variables include two continuous variables, years of schooling and years of age, and a set of dichotomous variables. The dichotomous variables include marital status (whether married, with spouse present), whether there are children under age 18 in the household, and whether the respondent lives in a rural area or a southern state (the swath of 17 states from Texas to the Atlantic Ocean, from Maryland to Florida, including Washington, DC).

The census asks, when did this person come to the United States to stay? The census does not ask the type of visa used to enter the United States or when permanent resident status was obtained. Given that many Soviet Jews entered the United States as asylees only to become permanent resident aliens (immigrants) at a later date, the census question is more appropriate

\footnotetext{
${ }^{3}$ Negative earnings can arise if the net losses from self-employment exceed the positive earnings from wages and salaries.
} 
for this analysis than is the year the respondent obtained permanent resident alien or immigrant status. Given the very low proportion of Soviet Jews who subsequently left the United States to return to the former Soviet Union or go to a third country, such as Israel, the emigration from the United States of Soviet immigrants does not pose a problem (Ahmed and Robinson, 1994 and Mulder 2003). ${ }^{4}$

Variables for duration in the United States are central to the analysis and they are entered as period of arrival dichotomous variables. ${ }^{5}$ This specification was chosen to permit a finer determination of non-linearities than would a quadratic specification or a continuous duration variable. Moreover, it increases comparability with earlier research on Soviet Jews in the United States. When duration is held constant, the age variable reflects the effect of age at migration on English language proficiency.

Another key variable is country of birth. A person born in any of the republics that constituted the former Soviet Union is considered to be a Soviet immigrant (FSU). ${ }^{6}$ Data are not

\footnotetext{
${ }^{4}$ Tolts (2004) also finds a very low re-migration rate of Soviet Jewish immigrants who arrive in Israel.

5 The period of arrival categories used here are: 1996-2000, 1991-1995, 1987-1990, 1985-1986, 1980-1984, 1975-1979, 1970-1974, and 1965-1969. For the proportion of the sample who arrived in each interval, see Appendix, Table A-4.

${ }^{6}$ In the 2000 Census, unlike previous censuses, there are republic of birth codes for each of the 15 republics in the former Soviet Union, as well as a generic "USSR" code. Excluding the 9 percent reporting Armenian by ancestry or language, 40 percent reported the Russian Republic, 32 percent the Ukraine, 9 percent the USSR, 4 percent Belarus, and 15 percent reported having been born in the other 12 Republics (Appendix Table A-3). In the earlier post-World War II censuses only the three Baltic Republics (Estonia, Latvia and Lithuania) were separately identified from the rest of the Soviet Union because the U.S. State Department did not recognize their incorporation into the Soviet Union.
} 
available on country of last permanent residence, so it is not possible to identify when a person left the former Soviet Union or from which republic, or whether there was a destination prior to

coming to the U.S. In this analysis the country categories Europe and Asia constitute all of Europe and Asia, other than parts of the former Soviet Union. Other country of origin groups are Canada, Latin America (including the Caribbean), and other countries (Africa, Oceania, etc.). Europe serves as the benchmark.

The econometric analysis of earnings is based on the human capital earnings function, modified for immigrant adjustment (Chiswick 1978). The natural logarithm of annual earnings in 1999 is regressed on years of schooling completed, years of potential labor market experience (age minus schooling minus 5 years), and its square, the natural logarithm of weeks worked, and dichotomous variables as defined above for being proficient in English, married spouse present, living in a rural area and living in a southern state. The same dichotomous variables are used, as defined above, for period of arrival and country of origin. Controlling for period of arrival, the labor market experience variable measures the effect on earnings in 1999 of experience in the country of origin.

\section{Econometric Analysis}

\section{a) Language - Soviet and Other Immigrants}

The results of the multiple regression analysis for the dependent variable, proficient in English, are reported here in prose. The full regression equations are available upon request in Appendix B. The variable is unity for those who speak only English at home or who speak 
another language but speak English very well or well, otherwise the English fluency variable is zero.

Consistent with what has been found elsewhere for immigrants, English language proficiency increases with years of schooling (3.5 percentage points more are proficient for each extra year of schooling). Proficiency is lower for those who immigrated at an older age. Men who are married are more proficient (by 4 percentage points), but children at home detracts from their proficiency (by 1.5 percentage points per child).

Duration in the United States has a major impact on English language proficiency. The coefficients are highly statistically significant and show a consistent gradient of increased proficiency with duration in the U.S., with the effect of an extra year in the United States becoming smaller the longer the duration of residence. With those who immigrated in 1980-84 as the benchmark, other variables the same, the most recent immigrants (1996-2000) were 25 percentage points less proficient in 2000, or the equivalent of the effect 7.2 years of schooling. The earliest cohort, 1965-69 immigrants, was 12 percentage points more proficient, or the equivalent of 3.5 years of schooling.

Other variables the same, Soviet immigrants are about 10 percentage points less likely to be proficient than other European immigrants. They are even less proficient than Asian immigrants ( 7 percentage points disadvantage compared to European immigrants), but less disadvantaged than those from Latin America (18 percentage point differential compared to European immigrants).

It is possible to test whether the effect of duration in the U.S. on proficiency in English differs between Soviet and other immigrants. The statistical analysis shows that during the first four years the negative effect on proficiency of being an immigrant is much greater for Soviet 
immigrants than it is for other immigrants. The coefficient suggests an additional 18.5 percentage point disadvantage among the most recent Soviet immigrants (1996-2000 cohort) and the effect is highly significant. There is no difference for other duration intervals; the duration Soviet Union interaction coefficients are all very small and are not statistically significant. Among those who immigrated in 1980-1984 (16 to 20 years in the U.S.), Soviet immigrants are only 5 percentage points less proficient than European immigrants (which includes those from the British Isles), compared to a 23 percentage point lower proficiency among those in the U.S. for 4 or fewer years. Indeed, the very large proportion of Soviet immigrants in the U.S. a short period of time and the very low English proficiency of this group are very important determinants of the overall low proficiency among Soviet immigrants.

The analysis was also performed for sub-periods within the 1965-2000 period. For each of these sub-periods the effects of schooling, age at immigration, marital status and children are quite similar. That is, their partial effects on proficiency in 2000 do not appear to vary by period of immigration. The effects of duration do vary by period of immigration. One fewer year in the U.S. has a larger negative effect on proficiency the more recently the immigrant cohort arrived in the U.S.

The results reported here for the 2000 Census can be compared with analyses reported previously for Soviet and other immigrants who came to the U.S. in 1965 or later, using the microdata files from the 1980 and 1990 Censuses (Chiswick 1993, 1997). The effects on English language proficiency of schooling, age, marital status, and rural residence are virtually identical across the three censuses, although the positive effects of living in the South is smaller in 2000 than in 1990. The negative effects of children in the household are also smaller in absolute value in 2000 than in 1990, but it was not significant in 1980. The strong positive effect 
of duration in the U.S. on proficiency is also observed in these earlier censuses. The very large negative effect of being in a particular immigrant cohort compared to an earlier arrival cohort diminishes from the 1980 to the 2000 Census as the cohorts are in the U.S. a longer period of time. For example, the 14 percentage points lower proficiency of the 1987-90 immigrant cohort compared to the $1980-84$ cohort in the 1990 Census is reduced to only nine percentage points lower proficiency ten years later in the 2000 Census.

The 10 percentage point disadvantage of being from the former Soviet Union compared to another part of Europe in the 2000 data is somewhat smaller than the 14 percentage points in the 1980 and 1990 Censuses. When the interaction terms of Soviet origin with duration are added, the Soviet intercept is a weakly significant 5 percentage points, compared to a nonsignificant 3 percentage points in 1990. Most striking is that in 1990 the only Soviet-duration of residence interaction term whose coefficient was large or statistically different from the benchmark (1980-84) was the most recent cohort, 1987-90 (coefficient of 26 percentage points). Ten years later, compared to the same benchmark, the 1987-90 interaction term has a coefficient of only 3 percentage points and it is not statistically significant.

These results suggest that the sharp gradient of English language proficiency with duration in the U.S. is not a consequence of declining proficiency among more recent cohorts. Rather it appears to be reflecting the acquisition of English language proficiency as a cohort has a longer duration in the U.S. Moreover, this initial deficiency and speed of adjustment appear to be more intense for Soviet Jews than from other immigrants. This may reflect their refugee motivated migration, the limited ability to prepare for the emigration because of the arbitrary nature of the Soviet bureaucracy, and the unexpected and sudden opening for emigration, with uncertainty as to how long emigration would be possible. 


\section{(b) Earnings - Soviet and Other Immigrants}

The analysis of earnings indicates that an extra year of schooling raises the earnings of immigrants by about 4.5 percent, that earnings increase at a decreasing rate with an increase in total labor market experience, that earnings rise by about 0.9 percent for each one percent increase in weeks worked (about one half of a week), and that earnings increase with duration of residence in the U.S. Indeed, compared to those who immigrated in 1980-84, those who recently arrived (immigrated 1996-2000) have about 16 percent lower weekly earnings, while those who immigrated in 1965 to 1969 had about 11 percent higher weekly earnings.

The country of origin effects are quite large. Compared to European immigrants, those from the Soviet Union had weekly earnings that were nearly 20 percent lower, other measured variables being the same. Only Latin American immigrants had a larger earnings disadvantage (about 32 percent) compared to those from Europe, while Canadian immigrants showed a large earnings advantage over Europeans (about 18 percent).

Other factors that resulted in higher earnings are being proficient in English (about 17.5 percent), being married (20 percent), living in an urban area (12 percent) and living outside the south (4 percent).

Other variables the same, an extra year of schooling is associated with 7.0 percent higher earnings for the Soviet Jewish immigrants, in contrast to the 4.5 percent for other immigrants, and the difference is highly statistically significant. Also, other things the same, the earnings of Soviet immigrants are much lower (and the difference is highly significant) than those of other immigrants during the first few years in the U.S. (immigrated 1996-2000 or 1991-1995), but the magnitude diminishes and becomes statistically insignificant for those who have been in the United States for ten or more years in 2000. 
Thus, the earnings gap between Soviet and other immigrants varies with duration in the U.S. and level of schooling. At the mean level of schooling of Soviet immigrants (14.9 years), those who immigrated in 1980 to 1984 (16 to 20 years in the U.S.) had about 7 percent higher weekly earnings than other European immigrants.

The comparison of these results with the 1990 Census analysis is striking (Chiswick 1997). In 1990 the effect of schooling on earnings was larger for Soviet immigrants by 1.9 percentage points and in 2000 by 2.6 percentage points, both of which were significantly different from zero, but not from each other. In 1990 the Soviet immigrant duration interaction term for the most recent arrivals was large and highly significant compared to the benchmark (1980-84 cohort), but the differential shrank with duration. Although only in the U.S. 6 to 10 years, at the mean level of schooling for Soviet immigrants (14.9 years), the earnings of the 1980-84 cohort of Soviet Jews was only one percent lower than that of other European immigrants. As in the 2000 Census, the larger return from schooling narrowed the earnings gap between Soviet and other immigrants in spite of a larger initial earnings disadvantage.

Among the Soviet immigrants, the 31 percent larger earnings disadvantage of the 198790 cohort compared to the $1984-85$ cohort in 1990 , shrank to a marginally significant $(t=1.6) 14$ percent disadvantage ten years later in 2000. This too suggests that what is being observed is an immigrant assimilation process rather than a change (deterioration) in the earnings potential of more recent cohorts.

Moreover, the lower initial earnings and the steeper rise in earnings with duration of residence in the U.S. of the Soviet immigrants, compared with other immigrant groups, is a phenomenon to be expected among refugee populations. Since their motives for migrating are 
not strictly economic, refugees tend to be less prepared for the move and to have skills that are less readily transferable to the destination.

\section{(c) Language and Earnings - Soviet Jewish Immigrants}

Parallel analyses to those reported above were performed separately for just the Soviet Jewish immigrants. The statistical significance of many of the variables is reduced because of the much smaller sample size. Of particular interest is whether there are differences among Soviet immigrants depending on their reported ethnic ancestries. Excluding those of Armenian ancestry or language, four groups are defined, Russian (46 percent of the sample), Ukrainian (22 percent), a response that revealed a person's religion (11 percent), and all other responses ( 21 percent). Those of Russian ancestry serve as the benchmark. Adding the ancestry variables to the equations has no material effect on the statistically significant variables in the analysis.

In the language analysis, other variables the same, differences are found in English language proficiency by ancestry. Those of Ukrainian origin are 6 percentage points less proficient in English than those of Russian ancestry, and the difference in highly significant. Those of "other ancestries" are 4 percentage points less proficient than the Russians, but this is at the margin of significance $(t=-1.7)$. There is no difference from those of Russian ancestry among those who gave a response indicating their religion (the coefficient indicates a 0.6 percent lower proficiency with a t-ratio of -0.19). The immigration sub-period analysis suggests that these differences in English language proficiency by ancestry are mainly due to the most recent (1985-2000) immigrants.

The analysis of earnings, other variables being the same, presents a different picture. For the post-1965 immigrants, there is no difference in earnings between the Russian, Ukrainian and religious revealing ancestries. Compared to the Russians, the Ukrainians had 2.7 percent lower 
earnings but a $\mathrm{t}=-0.49$, while those who gave a religious response had 1.4 percent higher earnings but a $t=0.20$. Only the heterogeneous group of other ancestries showed an earnings differential, a marginally significant $(\mathrm{t}=2.03), 11.3$ percent higher earnings.

The coefficients and significance levels of the other variables do not change when the ethnic ancestry variables are entered into the equation. The coefficient on the education variable in the analysis limited to Soviet Jewish immigrants is about 8.0 percent, whether or not the ancestry variables are held constant. This is a very large coefficient for an immigrant population in the United States. That it does not change when ancestry is held constant suggests that it holds across the ancestry groups.

\section{Summary and Conclusion}

This paper has been concerned with the English language proficiency and labor market earnings of adult (age 25 to 64 years) male Soviet Jews who immigrated to the United States since 1965. The data for the empirical analysis are from the 2000 Census of Population, Public Use Microdata Sample, one percent sample of the population. Comparisons are made to earlier parallel analyses using the 1980 and 1990 Censuses. Because of the absence of direct information on who is Jewish or of Jewish ancestry, the empirical analysis is based on persons born in the Former Soviet Union who are not of Armenian ancestry and do not speak Armenian at home.

The Soviet Jews were less proficient in English than other European immigrants and Asian immigrants. Under the definition of proficiency used in this study, 74 percent of the Soviet Jews were proficient, compared to 88 percent for European immigrants, 82 percent for Asian immigrants and 57 percent for those from Latin America. Their earnings (at $\$ 38,800$ in 
1999) were considerably less than the earnings of other European $(\$ 50,400)$ and Asian immigrants $(\$ 42,700)$ but were greater than the earnings of Latin American immigrants $(\$ 23,000)$.

The much higher level of schooling of the Soviet immigrants would tend to enhance their English proficiency; 14.9 years for the Soviet Jews, compared to 14.1 for Asian immigrants, 13.6 years for European immigrants, and 9.4 years for Latin American immigrants. On the other hand, the refugee motivations for their move and their recency of arrival would tend to lower their English language skills and earnings. Among those who immigrated since 1965, 72 percent of the FSU migrants were in the United States ten or fewer years, compared to only 37 percent of those from Europe, 36 percent of the Asians and 35 percent of the Latin Americans.

Multiple regression analysis is used to examine the effects of being a Soviet immigrant compared to coming from another region, when all other measured variables are held constant. It is found that recently arrived Soviet immigrants have a lower level of English proficiency than other European immigrants, but they have a faster rate of improvement. As a result the difference virtually disappears for those in the United States 16 to 20 years. The 1980 and 1990 Census data analyses show a similar pattern for recent immigrants. This appears to be a "life cycle" or longitudinal phenomenon, rather than inherently poorer English proficiency that will persist among the most recent cohorts.

Thus, the low level of English proficiency among Soviet immigrants is due to the low proficiency among recent arrivals and the large proportion that recently arrived. It is a temporary and not a permanent phenomenon.

The analysis of earnings, other measured variables the same, also shows much lower earnings among recent Soviet Jewish immigrants, but a steeper improvement with duration in the 
United States. The Soviet immigrants have a much larger positive effect of schooling on earnings compared to other immigrants. An extra year of schooling raises the earnings of Soviet Jewish immigrants by eight percent, compared to only 4.5 percent for other immigrants. As a result there is an earnings catch-up coming sooner the higher the level of schooling. Similar patterns were found in the analyses for the 1980 and 1990 Censuses.

Again, this suggests that the earnings disadvantage of Soviet Jewish immigrants as a group is short-lived and is due to the low earnings of recent arrivals and the disproportionate number of recent arrivals in the 2000 Census.

Analyses of English language proficiency and earnings were also performed among immigrants from the FSU (excluding the Armenians) by ancestry: Russian, Ukrainian, an ancestry response that reveals one's religion, and all other responses. In the language analysis, there was no difference in English proficiency, other variables the same, between those of Russian and religion response ancestries, although those who indicated Ukrainian were six percentage points less proficient. In the earnings analysis, other variables the same, there were no significant differences among these three groups.

Overall, it appears that Soviet Jewish immigrants adjust very well in the United States compared to other European immigrants. Their initial disadvantages in English language skills and earnings may be due to the refugee motivations for migration. With the passage of time this disadvantage disappears. For earnings it disappears most rapidly for those with higher levels of schooling. 


\section{REFERENCES}

Ahmed, Bashir and J. Gregory Robinson (1994), "Estimates of Emigration of the Foreign-Born Population: 1980-1990," U.S. Bureau of the Census, Population Division Technical Working Paper No. 9.

Chiswick, Barry R. (1978). "The Effect of Americanization on the Earnings of Foreignborn Men,” Journal of Political Economy, October, pp. 897-922.

Chiswick, Barry R. (1993). "Soviet Jews in the United States: An Analysis of Their Linguistic and Economic Adjustment," International Migration Review, 27(2), Summer, pp. 260286.

Chiswick, Barry R. (1997). "Soviet Jews in the United States: Language and Labor Market Adjustments Revisited," in Noah Lewin-Epstein, Yaacov Ro'i and Paul Ritterband, eds., Russian Jews on Three Continents: Migration and Resettlement, London: Frank Cass Publishers, pp. 233-260.

Chiswick, Barry R. and Paul W. Miller (1998). "English Language Fluency Among Immigrants in the United States," Research in Labor Economics, 17, pp. 151-200.

Mulder, Tammany J. (2003). "Foreign-born Emigration from the United States: 1990 to 2000," Paper presented at the Population Association of America, Annual Meeting, Minneapolis, May.

Tolts, Mark (2004). "Demographic Trends Among the Jews of the FSU," Paper presented at the International Conference on Soviet and Post-Soviet Jewry in Honor of Professor Mordechai Altshuler, Jerusalem, December 28-30, 2003. Revised January 12, 2004.

U.S. Bureau of the Census (2003). 2000 Census of Population and Housing, Public Use Microdata Sample, United States, Technical Documentation. 
Table 1

Immigration to the United States from Russia and the Soviet Union, $1820-2001^{(a)}$

\begin{tabular}{l|r} 
Time Period & Number of Immigrants \\
\hline $1820-30$ & 89 \\
$1831-40$ & 277 \\
$1841-50$ & 551 \\
$1851-60$ & 457 \\
$1861-70$ & 2,512 \\
$1871-80$ & 39,284 \\
$1881-90$ & 213,282 \\
$1891-1900$ & 505,290 \\
$1901-10$ & $1,597,306$ \\
$1911-20$ & 921,201 \\
$1921-30$ & 61,742 \\
$1931-40$ & 1,370 \\
$1941-50$ & 571 \\
$1951-60$ & 671 \\
$1961-70$ & 2,465 \\
$1971-80$ & 38,961 \\
$1981-90$ & 57,677 \\
$1991-2000$ & 462,874 \\
2001 & 55,099 \\
& \\
\hline Total & $3,961,665$
\end{tabular}

(a) Individuals granted permanent resident alien status. Includes all constituent units of Russia and of the Former Soviet Union.

Source: U.S. Department of Justice, 1993 Statistical Yearbook of the Immigration and Naturalization Service, Washington D.C., September 1994 and the U.S. Department of Justice, 2001 Statistical Yearbook of the Immigration and Naturalization Service, Washington D.C., February 2003. 
Table 2

Soviet Refugee and Asylee Arrivals and Admissions, FY 1961-2001

\begin{tabular}{|c|c|c|}
\hline Year & Dept of Justice $^{(a)}$ & Dept of State ${ }^{(b)}$ \\
\hline $1961-69$ & 456 & \\
\hline 1970 & 209 & \\
\hline 1971 & 88 & \\
\hline 1972 & 228 & \\
\hline 1973 & 591 & \\
\hline 1974 & 2,221 & \\
\hline 1975 & 3,209 & 6,211 \\
\hline 1976 & 5,882 & 7,450 \\
\hline TQ 1976 & 1,208 & \\
\hline 1977 & 5,296 & 8,191 \\
\hline 1978 & 9,931 & 10,688 \\
\hline 1979 & 27,135 & 24,449 \\
\hline 1980 & 28,692 & 28,444 \\
\hline 1981 & 11,244 & 13,444 \\
\hline 1982 & 2,838 & 2,756 \\
\hline 1983 & 1,449 & 1,409 \\
\hline 1984 & 791 & 715 \\
\hline 1985 & 674 & 640 \\
\hline 1986 & 833 & 787 \\
\hline 1987 & 3,728 & 3,694 \\
\hline 1988 & 18,880 & 20,421 \\
\hline 1989 & 39,831 & 39,553 \\
\hline 1990 & 53,130 & 50,716 \\
\hline 1991 & 57,587 & 38,661 \\
\hline 1992 & 66,026 & 61,298 \\
\hline 1993 & 51,983 & 48,627 \\
\hline 1994 & NA & 43,470 \\
\hline 1995 & NA & 35,716 \\
\hline 1996 & NA & 29,536 \\
\hline 1997 & NA & 27,072 \\
\hline 1998 & NA & 23,349 \\
\hline 1999 & NA & 17,220 \\
\hline 2000 & NA & 15,103 \\
\hline 2001 & NA & 15,749 \\
\hline 2002 & NA & 23,150 \\
\hline Total & 394,140 & 598,519 \\
\hline
\end{tabular}

(a) Soviet refugee and asylee approvals, fiscal year 1961-1993. TQ1976 means transition quarter when fiscal year was adjusted to start October 1 rather than July 1.

(b) Refugee admissions from the Soviet Union, 1976-2001, including all republics from the former Soviet Union.

Source: U.S. Department of Justice, 2001 Statistical Yearbook of the Immigration and Naturalization Service, Washington, DC, February 2003, Table 24. U.S. Department of Homeland Security, Yearbook of Immigration Statistics, 2002, Washington, DC 2003. 
Table 3

Selected Characteristics of Adult Males who Immigrated Since 1965 by Region of Birth, 2000

\begin{tabular}{|c|c|c|c|c|c|}
\hline Variable $^{(\mathrm{a})}$ & $\begin{array}{r}\text { Former Soviet } \\
\text { Union }^{(\mathrm{b})} \\
\end{array}$ & $\begin{array}{r}\text { Europe } \\
\text { (Excluding } \\
\text { FSU) } \\
\end{array}$ & Asia & Latin America & Total $^{(\mathrm{c})}$ \\
\hline \multicolumn{6}{|c|}{ (A) Means and Standard Deviations } \\
\hline \multirow[t]{2}{*}{ Age } & 42.3 & 42.6 & 41.1 & 38.2 & 39.6 \\
\hline & 10.9 & 10.4 & 10.3 & 9.6 & 10.0 \\
\hline \multirow{2}{*}{ Education (years) } & 14.9 & 13.6 & 14.1 & 9.4 & 11.5 \\
\hline & 3.3 & 3.8 & 3.9 & 4.7 & 4.9 \\
\hline \multirow[t]{2}{*}{ Earnings (\$) } & 38,777 & 50,398 & 42,673 & 23,031 & 32,615 \\
\hline & 50,416 & 60,191 & 54,608 & 30,405 & 45,229 \\
\hline \multirow[t]{2}{*}{ Log of Earnings } & 9.42 & 9.95 & 9.66 & 9.19 & 9.43 \\
\hline & 2.25 & 1.98 & 2.09 & 1.91 & 2.00 \\
\hline \multirow{2}{*}{ Weeks Worked } & 46.5 & 47.7 & 46.9 & 45.2 & 46.0 \\
\hline & 11.1 & 9.8 & 10.6 & 11.7 & 11.2 \\
\hline \multicolumn{6}{|l|}{ (B) Percents } \\
\hline \multicolumn{6}{|c|}{ Period of Immigration } \\
\hline 1995-2000 & 33.4 & 21.9 & 19.1 & 17.9 & 19.6 \\
\hline 1990-1994 & 37.4 & 14.8 & 17.6 & 17.0 & 17.4 \\
\hline 1985-1989 & 11.3 & 13.4 & 17.0 & 21.5 & 18.8 \\
\hline 1980-1984 & 6.1 & 11.4 & 19.0 & 17.3 & 16.8 \\
\hline $1975-1979$ & 9.5 & 11.4 & 14.9 & 11.6 & 12.4 \\
\hline $1970-1974$ & 1.4 & 12.4 & 8.2 & 9.4 & 9.2 \\
\hline 1965-1969 & $\underline{.9}$ & $\underline{14.7}$ & 4.2 & $\underline{5.4}$ & $\underline{6.0}$ \\
\hline Total & 100.0 & $\overline{100.0}$ & $10 \overline{100}$ & $10 \overline{100}$ & 100.0 \\
\hline Married & 74.0 & 69.0 & 67.6 & 56.3 & 61.2 \\
\hline Speaks English ${ }^{(\mathrm{d})}$ & 73.0 & 88.4 & 82.3 & 57.1 & 69.5 \\
\hline With Children & 51.5 & 45.0 & 54.2 & 67.8 & 60.4 \\
\hline Rural Residence & 0.5 & .07 & 0.6 & 1.6 & 1.2 \\
\hline Southern States & 10.2 & 20.7 & 19.6 & 32.4 & 27.3 \\
\hline Unemployed $^{(\mathrm{e})}$ & 3.6 & 2.4 & 2.7 & 5.1 & 4.1 \\
\hline Sample Size & 1,721 & 8,578 & 24,416 & 50,280 & 90,384 \\
\hline
\end{tabular}


(a) Means in Bold. Standard Deviations below. Percents with specific characteristics.

(b) Former Soviet Union excludes persons of Armenian ancestry or language.

(c) Total includes groups not shown separately.

(d) Speaks only English at home or speaks another language but speaks English very well or well.

(e) Unemployment as a percent of the labor force.

Source: 2000 Census of Population, Public Use Microdata Sample, 1 percent sample. 
Table 4

Fluency in English Among Adult Male Immigrants

Who Immigrated Since $1965^{\text {(a) }}$

(percent)

\begin{tabular}{rrrrrr}
\hline $\begin{array}{r}\text { English } \\
\text { Fluency }\end{array}$ & $\begin{array}{r}\text { Former } \\
\text { Soviet } \\
\text { Union }\end{array}$ & $\begin{array}{r}\text { Europe } \\
\text { (Excluding } \\
\text { FSU) }\end{array}$ & Asia & $\begin{array}{r}\text { Latin } \\
\text { America }\end{array}$ & $\begin{array}{r}\text { All } \\
\text { Immigrants }\end{array}$ \\
\hline $\begin{array}{r}\text { Speaks only } \\
\text { English at home }\end{array}$ & 4.5 & 32.3 & 7.4 & 10.7 & 13.4 \\
$\begin{array}{r}\text { Speaks another } \\
\text { Language at home }\end{array}$ & & & & & \\
and speaks English: & 30.1 & 36.6 & 45.3 & 22.0 & 31.1 \\
Very Well & 37.8 & 19.9 & 29.4 & 24.6 & 25.1 \\
Well & 22.5 & 9.6 & 15.4 & 28.2 & 21.4 \\
Not Well & 4.3 & 1.6 & 2.5 & 14.5 & 9.0 \\
Not at All & 100.0 & 100.0 & 100.0 & 100.0 & 100.0 \\
Total & & & & & \\
& 8,373 & 42,590 & 124,735 & 250,826 & 451,844 \\
\hline
\end{tabular}

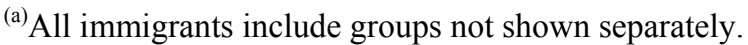

Former Soviet Union excludes persons of Armenian ancestry or language.

Note: Detail may not add to total due to rounding.

Source: 2000 Census of Population, Public Use Microdata Sample, 1 percent sample. 


\section{Appendix Table A-1}

\section{Ancestry or Ethnic Origin of Adult Male Soviet Immigrants \\ Who Immigrated Since 1965, 2000 \\ (percent)}

\begin{tabular}{lrrrr}
\hline Ethnic & \multicolumn{4}{c}{ Period of Immigration } \\
Ancestry & $1965-2000$ & $1965-1979$ & $1980-1989$ & $1990-2000$ \\
\hline Russian & 41.1 & 36.7 & 39.1 & 41.4 \\
Religion ${ }^{(a)}$ & 9.6 & 10.9 & 9.6 & 9.7 \\
Armenian & 10.8 & 12.7 & 17.1 & 9.8 \\
Ukrainian & 19.9 & 18.9 & 18.3 & 20.9 \\
Not Reported & 5.8 & 6.7 & 7.3 & 5.4 \\
Soviet Union, n.e.c. ${ }^{(b)}$ & 4.7 & 1.3 & 1.1 & 5.4 \\
Lithuanian & 1.5 & 0.8 & 1.3 & 1.5 \\
Latvian & 0.8 & 1.6 & 1.5 & 0.5 \\
Polish & 0.3 & 1.3 & 0.0 & 0.1 \\
All Other & $\underline{5.5}$ & $\underline{9.1}$ & $\underline{4.7}$ & $\underline{5.3}$ \\
Total & 100.0 & 100.0 & 100.0 & 100.0 \\
\hline
\end{tabular}

Note: Detail may not add to total due to rounding.

(a) Response to ancestry question indicating the person's religion or religious origin, ancestry code 998.

(b) Includes Azerbaijani, Belorussian, Estonian, Ossetian, Moldavian, Tatar, Turkestani, Uzbek, Georgian, Tajik and those who reported Soviet Union.

Source: 2000 Census of Population, Public Use Microdata Sample, 1 percent sample. 


\section{Appendix Table A-2}

Language Spoken in the Home by Adult Males Who Immigrated from the Former Soviet Union Since 1965 to $2000^{(a)}$ (percent)

\begin{tabular}{lcccc}
\hline & & \multicolumn{3}{c}{ Period of Immigration } \\
Language & $1965-2000$ & $1965-1979$ & $1980-1989$ & $1990-2000$ \\
\hline English only & 4.0 & 9.2 & 5.0 & 3.1 \\
Russian & 71.6 & 63.3 & 69.4 & 73.4 \\
Armenian & 9.4 & 12.7 & 17.3 & 8.0 \\
Ukrainian & 7.2 & 2.5 & 2.5 & 8.4 \\
Yiddish & 0.2 & 0.4 & 0.0 & 0.1 \\
Other & $\underline{7.6}$ & $\underline{11.9}$ & $\underline{5.8}$ & $\underline{7}$ \\
Total & 100.0 & 100.0 & 100.0 & 100.0 \\
\hline
\end{tabular}

Note: Detail may not add to total due to rounding.

(a) Language currently spoken in the home other than or in addition to English.

Source: 2000 Census of Population, Public Use Microdata Sample, 1 percent sample. 
Appendix Table A-3

Republic of Birth of Immigrants from the Former Soviet Union, Adult Males, 25 to 64, 2000.

\begin{tabular}{|c|c|c|c|c|c|c|c|c|}
\hline $\begin{array}{l}\text { Republic of } \\
\text { Birth }\end{array}$ & $\begin{array}{r}\text { Immigration Per } \\
1965-2000 \\
\text { Non-Armenian }^{(a)}\end{array}$ & od & $\begin{array}{r}\text { 1965-1979 } \\
\text { Non- } \\
\text { Armenian }^{(\mathrm{a})}\end{array}$ & All & $\begin{array}{c}\text { 1980-1989 } \\
\text { Non- } \\
\text { Armenian }^{(a)}\end{array}$ & All & $\begin{array}{c}\text { 1990-2000 } \\
\text { Non- } \\
\text { Armenian }^{\text {(a) }}\end{array}$ & riod \\
\hline Estonia & 4 & 4 & 2 & 2 & 1 & 1 & 1 & 1 \\
\hline Latvia & 31 & 31 & 6 & 6 & 9 & 9 & 16 & 16 \\
\hline Lithuania & 35 & 35 & 2 & 2 & 7 & 7 & 26 & 26 \\
\hline Armenia & 15 & 191 & 0 & 30 & 3 & 35 & 12 & 126 \\
\hline Azerbaijan & 23 & 32 & 0 & 0 & 4 & 5 & 19 & 27 \\
\hline Belarus & 72 & 72 & 4 & 4 & 14 & 14 & 54 & 54 \\
\hline Georgia & 31 & 37 & 3 & 3 & 4 & 5 & 24 & 29 \\
\hline Moldova & 49 & 49 & 2 & 2 & 5 & 5 & 42 & 42 \\
\hline Russia & 681 & 691 & 76 & 76 & 91 & 92 & 514 & 523 \\
\hline Ukraine & 545 & 547 & 73 & 73 & 67 & 68 & 405 & 406 \\
\hline $\mathrm{USSR}^{(\mathrm{b})}$ & 153 & 156 & 22 & 22 & 59 & 59 & 72 & 75 \\
\hline Kazakhstan & 22 & 23 & 0 & 0 & 2 & 3 & 20 & 20 \\
\hline Kyrgyzstan & 5 & 5 & 0 & 0 & 0 & 0 & 5 & 5 \\
\hline Tajikstan & 8 & 8 & 0 & 0 & 3 & 3 & 5 & 5 \\
\hline Turkmenistan & 1 & 2 & 0 & 0 & 0 & 0 & 1 & 2 \\
\hline Uzbekistan & 46 & 46 & 1 & 1 & 2 & 2 & 43 & 43 \\
\hline Total & 1,721 & 1,929 & 191 & 221 & 271 & 308 & 1,259 & 1,400 \\
\hline
\end{tabular}

(a) Excludes persons reporting an Armenian Ancestry.

(b) Persons reporting USSR rather than a specific republic.

Source: 2000 US Census of Population, Public Use Microdata Sample, 1 percent sample 


\section{Appendix Table A-4}

Period of Immigration for Adult Male Immigrants

Born in the Former Soviet Union, Including Armenians, 2000.

(percent)

$\underline{\text { Period of Immigration }}$

$1995-2000$

$1990-1994$

1985-1989

$1980-1984$

$1975-1979$

1970-1974

$1965-1969$

1960-1964

1950-1959

Before 1950

Total $\underline{\text { All Years }}$

37.4

26.3

12.7

8.2

6.1

2.7

2.1

1.9

1.5

$\underline{0.9}$

100.0 $\underline{\text { Since } 1965}$

38.7

27.4

13.2

8.6

6.4

2.8

2.2

$-$

--

-

100.0

Note: Detail may not add to total due to rounding.

Source: 2000 Census of Population, Public Use Microdata Sample, 1 percent sample. 
Appendix Table B1: Regression Analysis of Fluency in English among Adult Males who Immigrated since 1965: 2000

Dependent Variable=ZENGSPK

\begin{tabular}{|c|c|c|c|c|c|c|c|c|}
\hline \multirow{2}{*}{$\begin{array}{c}\text { Immigration } \\
\text { Period: } \\
\text { Variable }\end{array}$} & \multicolumn{2}{|c|}{$1965-2000$} & \multicolumn{2}{|c|}{ 1965-1979 } & \multicolumn{2}{|c|}{ 1975-1989 } & \multicolumn{2}{|c|}{$1985-2000$} \\
\hline & (1) & (2) & (1) & (2) & (1) & (2) & (1) & (2) \\
\hline CONSTANT & .7177 & .7188 & .7929 & .7929 & .7258 & .7261 & .7249 & .7268 \\
\hline & 74.75 & 74.87 & 50.76 & 50.76 & 51.41 & 51.43 & 52.90 & 52.98 \\
\hline EDUCYRS & .0347 & .0347 & .0335 & .0335 & .0363 & .0363 & .0344 & .0343 \\
\hline & 113.15 & 113.12 & 66.82 & 66.79 & 83.08 & 83.08 & 77.87 & 77.80 \\
\hline AGE & $\begin{array}{l}-.0066 \\
-44.38\end{array}$ & $\begin{array}{r}-.0067 \\
-44.49\end{array}$ & $\begin{array}{l}-.0064 \\
-26.12\end{array}$ & $\begin{array}{r}-.0064 \\
-2612\end{array}$ & $\begin{array}{l}-.0074 \\
-3365\end{array}$ & $\begin{array}{l}-.0074 \\
-33.66\end{array}$ & $\begin{array}{l}-.0065 \\
-30.45\end{array}$ & $\begin{array}{l}-.0065 \\
-3060\end{array}$ \\
\hline IM96_00 & -.2492 & -.2443 & & & & & -.2236 & -.2194 \\
\hline & -52.88 & -51.50 & & & & & -35.69 & -34.90 \\
\hline IM91_95 & -.1626 & -.1639 & & & & & -.1339 & -.1358 \\
\hline & $\begin{array}{r}-35.26 \\
0\end{array}$ & -35.27 & & & & & -21.81 & -22.04 \\
\hline IM87_90 & $\begin{array}{r}-.0876 \\
-18.99\end{array}$ & $\begin{array}{r}-.0891 \\
-19.23\end{array}$ & & & $\begin{array}{r}-.0842 \\
-16.62\end{array}$ & $\begin{array}{r}-.0847 \\
-16.64\end{array}$ & $\begin{array}{r}-.0528 \\
-8.65\end{array}$ & $\begin{array}{r}-.0545 \\
-8.91\end{array}$ \\
\hline IM85_86 & -.0347 & -.0345 & & & -.0392 & -.0390 & * & * \\
\hline & -6.07 & -6.04 & & & -16.62 & -16.64 & & \\
\hline IM75_79 & .0544 & .0545 & -.0499 & -.0498 & .0577 & .0586 & & \\
\hline IM70_74 & $\begin{array}{r}11.07 \\
.1069 \\
19.64\end{array}$ & $\begin{array}{r}11.06 \\
.1073 \\
19.68\end{array}$ & $\begin{array}{r}-10.06 \\
*\end{array}$ & $\begin{array}{r}-10.01 \\
*\end{array}$ & 11.82 & 11.95 & & \\
\hline IM65_69 & $\begin{array}{r}.1222 \\
19.04\end{array}$ & $\begin{array}{r}.1222 \\
1902\end{array}$ & .0241 & .0238 & & & & \\
\hline $\begin{array}{l}\text { IM96_00*FSUJ } \\
\text { EW }\end{array}$ & 19.04 & $\begin{array}{r}19.02 \\
-.1849\end{array}$ & 4.03 & 3.98 & & & & -.1522 \\
\hline $\begin{array}{l}\text { IM91_95*FSUJ } \\
\text { EW }\end{array}$ & & $\begin{array}{r}-6.36 \\
-.0147\end{array}$ & & & & & & $\begin{array}{r}-4.09 \\
.0143\end{array}$ \\
\hline $\begin{array}{l}\text { IM87_90*FSUJ } \\
\text { EW }\end{array}$ & & $\begin{array}{r}-0.53 \\
.0328\end{array}$ & & & & .0159 & & $\begin{array}{r}0.40 \\
.0551\end{array}$ \\
\hline $\begin{array}{l}\text { IM85_86*FSUJ } \\
\text { EW }\end{array}$ & & $\begin{array}{r}1.00 \\
.0036\end{array}$ & & & & $\begin{array}{r}.037 \\
-.0253\end{array}$ & & $\begin{array}{r}1.35 \\
*\end{array}$ \\
\hline $\begin{array}{l}\text { IM75_79*FSUJ } \\
\text { EW }\end{array}$ & & $\begin{array}{r}0.04 \\
-.0386\end{array}$ & & -.0090 & & $\begin{array}{r}-0.29 \\
-.0734\end{array}$ & & \\
\hline IM70_74*FSUJ & & $\begin{array}{r}-0.99 \\
-.0421\end{array}$ & & $\begin{array}{r}-0.18 \\
*\end{array}$ & & -1.72 & & \\
\hline $\begin{array}{l}\text { IM65_69*FSUJ } \\
\text { EW }\end{array}$ & & $\begin{array}{r}-0.58 \\
.0514\end{array}$ & & .0701 & & & & \\
\hline MARRSP & 0397 & $\begin{array}{r}0.57 \\
0399\end{array}$ & 0239 & $\begin{array}{r}0.81 \\
0239\end{array}$ & 0223 & 0223 & 0043 & 0046 \\
\hline & 12.98 & 13.05 & & & & 5.01 & 10.40 & 10.46 \\
\hline RURAL & .0188 & .0189 & .0156 & .0157 & .0409 & .0411 & .0230 & .0230 \\
\hline & 1.58 & 1.59 & 0.77 & 0.77 & 2.35 & 2.36 & 1.42 & 1.43 \\
\hline
\end{tabular}




\begin{tabular}{|c|c|c|c|c|c|c|c|c|}
\hline SOUTH & .0083 & .0083 & .0054 & .0054 & .0105 & .0105 & .0087 & .0087 \\
\hline & & 2.79 & 1.08 & 1.08 & 2.41 & 2.42 & 2.06 & 2.06 \\
\hline \multirow[t]{2}{*}{ CHILD } & -.0149 & -.0146 & -.0078 & -.0078 & -.0051 & -.0052 & -.0231 & -.0228 \\
\hline & -4.98 & -4.88 & -1.59 & -1.60 & -1.13 & -1.15 & -5.47 & -5.38 \\
\hline \multirow[t]{2}{*}{ FSU } & -.0980 & -.0499 & -.0307 & -.0309 & -.0222 & -.0044 & -.1455 & -.1146 \\
\hline & -10.00 & -2.18 & -1.37 & -0.73 & -1.23 & -0.15 & -12.11 & -3.64 \\
\hline \multirow[t]{2}{*}{ ASIA } & -.0734 & -.0754 & -.0695 & -.0696 & -.0885 & -.0891 & -.0793 & -0.804 \\
\hline & -15.05 & -15.20 & -9.55 & -9.53 & -11.45 & -11.47 & -11.01 & -10.96 \\
\hline \multirow{2}{*}{ LATAMER } & -.1768 & -1778 & -.0963 & -.0963 & -.1492 & -.1496 & -.2423 & -.2431 \\
\hline & -36.33 & -36.38 & -13.97 & -13.97 & -19.28 & -19.27 & -33.41 & -33.23 \\
\hline \multirow{2}{*}{ CANADA } & .0825 & .0812 & -.0018 & -.0018 & .0315 & .0310 & .1304 & .1292 \\
\hline & 7.73 & 7.60 & -0.12 & -0.12 & 1.64 & 1.62 & 8.61 & 8.51 \\
\hline \multirow[t]{2}{*}{ OTHER } & .0621 & .0601 & -.0089 & -.0091 & .0145 & .0141 & .0861 & .0849 \\
\hline & 7.91 & 7.73 & -0.67 & & 1.19 & 1.15 & 7.88 & 7.74 \\
\hline SAMPLE SIZE & 90383 & 90383 & 24847 & 24847 & 43351 & 43351 & 50380 & 50380 \\
\hline STANDARD ERROR & .3931 & .3929 & .3351 & .3351 & .3896 & .3896 & .4174 & .4172 \\
\hline$R 2$ & .2711 & .2718 & 2543 & .2543 & 2367 & .2368 & .2578 & 2587 \\
\hline ADJUSTED R2 & .2710 & .2716 & .2539 & .2539 & .2365 & .2365 & 2576 & .2584 \\
\hline
\end{tabular}

Estimted coefficients in BOLD, t-ratios below.

*omitted as benchmark; 1980-1984 and EUROPE are benchmarks unless otherwise noted.

Source: 2000 U.S. Census of Population, Public Use Microdata Sample, 5\% Sample 
Appendix Table B-1A Regression Analysis of English Fluency Among Adult Males

Who Immigrated Since 1965: 2000, 1990, 1980. Dependent Variable=ENGSPK

\begin{tabular}{|c|c|c|c|c|c|}
\hline $\begin{array}{c}\text { Immigration } \\
\text { Period: } \\
\text { Variable }\end{array}$ & \multicolumn{2}{|c|}{$\begin{array}{r}2000 \text { Census } \\
1965-2000\end{array}$} & \multicolumn{2}{|c|}{$\begin{array}{r}1990 \text { Census } \\
1965-1989\end{array}$} & $\begin{array}{r}1980 \text { Census } \\
1965-1979 \\
(1)\end{array}$ \\
\hline CONSTANT & $\begin{array}{r}.7177 \\
7475\end{array}$ & $\begin{array}{r}.7188 \\
7487\end{array}$ & $\begin{array}{r}6031 \\
11499\end{array}$ & $\begin{array}{r}.6027 \\
114.94\end{array}$ & $\begin{array}{r}.5243 \\
4160\end{array}$ \\
\hline EDUCYRS & $\begin{array}{r}.0347 \\
113.15\end{array}$ & $\begin{array}{l}.0347 \\
113.12\end{array}$ & $\begin{array}{r}.0356 \\
19266\end{array}$ & $\begin{array}{r}.0355 \\
19259\end{array}$ & $\begin{array}{r}.0388 \\
8992\end{array}$ \\
\hline AGE & $\begin{array}{r}-.0066 \\
-44.38\end{array}$ & $\begin{array}{r}-.0067 \\
-44.49\end{array}$ & $\begin{array}{r}-.0067 \\
-73.07\end{array}$ & $\begin{array}{r}-.0067 \\
-73.30\end{array}$ & $\begin{array}{r}-.0050 \\
-20.26\end{array}$ \\
\hline IM96_00 & $\begin{array}{r}-.2492 \\
-52.88\end{array}$ & $\begin{array}{r}-.2443 \\
-51.50\end{array}$ & & & \\
\hline IM91_95 & $\begin{array}{r}-1626 \\
-3526\end{array}$ & $\begin{array}{r}-1639 \\
3527\end{array}$ & & & \\
\hline IM87_90 & $\begin{array}{r}-.0876 \\
-18.99\end{array}$ & $\begin{array}{r}-.0891 \\
-19.23\end{array}$ & $\begin{array}{r}-.1387 \\
-51.87\end{array}$ & $\begin{array}{r}-.1341 \\
-49.77\end{array}$ & \\
\hline IM85_86 & $\begin{array}{r}-.0347 \\
-6.07\end{array}$ & $\begin{array}{r}-.0345 \\
-6.04\end{array}$ & $\begin{array}{r}-.0698 \\
-23.07\end{array}$ & $\begin{array}{r}-.0693 \\
-22.85\end{array}$ & \\
\hline IM75_79 & $\begin{array}{r}.0544 \\
11.07\end{array}$ & $\begin{array}{r}.0546 \\
11.06\end{array}$ & $\begin{array}{r}.0796 \\
33.12\end{array}$ & $\begin{array}{r}.0789 \\
32.64\end{array}$ & $\begin{array}{r}-.0956 \\
-19.20\end{array}$ \\
\hline IM70_74 & $\begin{array}{r}1069 \\
19.64\end{array}$ & $\begin{array}{r}.1073 \\
19.68\end{array}$ & $\begin{array}{r}.1312 \\
50.16\end{array}$ & $\begin{array}{r}.1316 \\
50.21\end{array}$ & * \\
\hline IM65_69 & $\begin{array}{r}.1222 \\
19.04\end{array}$ & $\begin{array}{r}.1222 \\
19.02\end{array}$ & $\begin{array}{r}.1690 \\
58.01\end{array}$ & $\begin{array}{r}.1695 \\
58.13\end{array}$ & $\begin{array}{r}.0574 \\
11.18\end{array}$ \\
\hline $\begin{array}{l}\text { IM96_00*FSUJ } \\
\text { EW }\end{array}$ & & -.1580 & & & \\
\hline $\begin{array}{l}\text { IM91_95*FSUJ } \\
\text { EW }\end{array}$ & & -.0147 & & & \\
\hline $\begin{array}{l}\text { IM87_90*FSUJ } \\
\text { EW }\end{array}$ & & $\begin{array}{r}-0.53 \\
.03281\end{array}$ & & -.2527 & \\
\hline $\begin{array}{l}\text { IM85_86*FSUJ } \\
\text { EW }\end{array}$ & & $\begin{array}{r}1.00 \\
.0036\end{array}$ & & $\begin{array}{r}-10.31 \\
-.0456\end{array}$ & \\
\hline $\begin{array}{l}\text { IM75_79*FSUJ } \\
\text { EW }\end{array}$ & & $\begin{array}{r}0.04 \\
-.0386\end{array}$ & & $\begin{array}{r}-0.85 \\
-.0249\end{array}$ & \\
\hline $\begin{array}{l}\text { IM70_74*FSUJ } \\
\text { EW }\end{array}$ & & $\begin{array}{r}-0.99 \\
-.0421\end{array}$ & & $\begin{array}{r}-1.00 \\
-.0346\end{array}$ & \\
\hline $\begin{array}{l}\text { IM65_69*FSUJ } \\
\text { EW }\end{array}$ & & $\begin{array}{r}-0.58 \\
.0514\end{array}$ & & $\begin{array}{r}-0.87 \\
.0263\end{array}$ & \\
\hline & & 0.57 & & .45 & \\
\hline MARRSP & $\begin{array}{r}.0397 \\
12.98\end{array}$ & $\begin{array}{r}.0399 \\
13.05\end{array}$ & $\begin{array}{r}.0404 \\
20.53\end{array}$ & $\begin{array}{r}.0409 \\
20.78\end{array}$ & $\begin{array}{r}.0134 \\
2.17\end{array}$ \\
\hline $\begin{array}{l}\text { RURAL } \\
\text { SOUTH }\end{array}$ & $\begin{array}{r}.0188 \\
1.58 \\
.0083\end{array}$ & $\begin{array}{r}.0189 \\
1.59 \\
.0083\end{array}$ & $\begin{array}{r}.0177 \\
4.55 \\
.0174\end{array}$ & $\begin{array}{r}.0177 \\
4.55 \\
.0175\end{array}$ & $\begin{array}{r}.0102 \\
1.16 \\
.0030\end{array}$ \\
\hline
\end{tabular}




\begin{tabular}{|c|c|c|c|c|c|}
\hline & 2.79 & 2.79 & 8.99 & 9.03 & 0.60 \\
\hline CHILD & -.0149 & -.0147 & -.0267 & -0.260 & .0093 \\
\hline \multirow{2}{*}{\multicolumn{5}{|c|}{ FORMAR (a) }} & 1.98 \\
\hline & & & & & $\begin{array}{r}-.0431 \\
832\end{array}$ \\
\hline \multirow[t]{2}{*}{ FSU } & -.0979 & -.0492 & -.1374 & -.0273 & -.1384 \\
\hline & -10.00 & -2.18 & -16.05 & -1.31 & -7.47 \\
\hline ASIA & $\begin{array}{r}-.0739 \\
-15.05\end{array}$ & $\begin{array}{r}-.0754 \\
-15.20\end{array}$ & $\begin{array}{r}-.0632 \\
-22.43\end{array}$ & $\begin{array}{r}-.0631 \\
-22.43\end{array}$ & $\begin{array}{r}-.0431 \\
-6.97\end{array}$ \\
\hline \multirow[t]{2}{*}{ LATAMER } & -.1768 & -.1777 & -.1514 & -.1514 & -.1445 \\
\hline & -36.33 & -36.38 & -54.87 & -54.88 & -25.13 \\
\hline \multirow{2}{*}{ CANADA } & .0825 & .0812 & .0739 & .0739 & .1265 \\
\hline & 7.73 & 7.60 & 11.05 & 11.06 & 9.26 \\
\hline OTHER & $\begin{array}{r}.0621 \\
7.91\end{array}$ & $\begin{array}{r}.0601 \\
7.73\end{array}$ & $\begin{array}{c}-.0228 \\
-6.10\end{array}$ & $\begin{array}{r}-.0227 \\
-6.08\end{array}$ & $\begin{array}{r}.0202 \\
2.41\end{array}$ \\
\hline SAMPLE SIZE & 90383 & 90383 & 227554 & 227554 & 35915 \\
\hline STANDARD ERROR & 39307 & .3929 & .3879 & .3877 & .3790 \\
\hline R2 & .2711 & .2718 & .2649 & .2656 & .3047 \\
\hline ADJUSTED R2 & .2710 & .2716 & .2649 & .2655 & .3044 \\
\hline
\end{tabular}

Appendix Table B-1A Notes:

Estimated Coefficients in Bold. T-ratios below.

(a) Variable cannot be reconstructed for 1990, 2000 Census.

*omitted as benchmark; benchmark is 1980-1984 and EUROPE unless otherwise noted.

Source: 2000 Census of Population, Public Use Microdata Sample, 5\% Sample. 1990 Census of Population, Public Use Microdata Sample, 5\% Sample.

1980 Census of Population, Public Use Sample, B and C Sample Files Combined, 2\% Sample. 
Appendix Table B-2: Regression Analysis of Earnings Among Adult Males Who Immigrated Since 1965

Dependent Variable $=$ LNEARN

\begin{tabular}{|c|c|c|c|c|c|c|c|c|}
\hline & & & 200 & ensus & & & & \\
\hline & 196 & -2000 & 196 & -1979 & 198 & -1989 & 199 & -2000 \\
\hline Variable & (1) & (2) & (1) & (2) & (1) & $(2)$ & (1) & (2) \\
\hline CONSTANT & 6.198 & 6.202 & 5.979 & 5.981 & 6.487 & 6.486 & 6.265 & 6.274 \\
\hline & 200.12 & 200.29 & 93.59 & 93.61 & 141.68 & 141.64 & 154.80 & 154.94 \\
\hline EDUCYRS & .0451 & .0447 & .0551 & .0549 & .0440 & .0438 & .0404 & .0398 \\
\hline & 57.14 & 56.49 & 33.56 & 33.35 & 39.35 & 39.13 & 39.10 & 38.35 \\
\hline EXP & .0102 & .0103 & .0098 & .0098 & .0124 & .0124 & .0090 & .0089 \\
\hline & & & 4.39 & 4.38 & 7.51 & 7.50 & 6.08 & 6.01 \\
\hline EXPSQ & -.00017 & -.00017 & .00014 & -.00014 & -.00022 & -.00022 & -.00016 & -.00016 \\
\hline & -8.72 & -8.83 & -3.61 & -3.61 & -7.51 & -7.52 & -5.80 & -5.80 \\
\hline LNWW & .8679 & .8675 & .8954 & .8951 & .8002 & .8001 & .8762 & .8756 \\
\hline & $\begin{array}{r}145.45 \\
1508\end{array}$ & 145.44 & 69.17 & 69.15 & 89.39 & 89.38 & 117.02 & 117.01 \\
\hline IM96_00 & $\begin{array}{r}-.1598 \\
-15.34\end{array}$ & $\begin{array}{r}-.1506 \\
-14.37\end{array}$ & & & & & $\begin{array}{r}-.1244 \\
-9.88\end{array}$ & $\begin{array}{r}-.1177 \\
-9.31\end{array}$ \\
\hline IM91_95 & $\begin{array}{r}-1229 \\
-12.53\end{array}$ & $\begin{array}{r}-1205 \\
-12.19\end{array}$ & & & & & $\begin{array}{r}-.0828 \\
-6.90\end{array}$ & $\begin{array}{r}-.0830 \\
-6.89\end{array}$ \\
\hline IM87_90 & $\begin{array}{r}-.0692 \\
-7.13\end{array}$ & $\begin{array}{r}-.0705 \\
-7.23\end{array}$ & & & $\begin{array}{r}-.0632 \\
-5.93\end{array}$ & $\begin{array}{r}-.0629 \\
-5.86\end{array}$ & $\begin{array}{r}-.0263 \\
-2.22\end{array}$ & $\begin{array}{r}-.0291 \\
-2.45\end{array}$ \\
\hline IM85_86 & -.0448 & -.0429 & & & -.0461 & -.0449 & * & * \\
\hline IM75 79 & $\begin{array}{r}-3.75 \\
0561\end{array}$ & $\begin{array}{r}-3.59 \\
\mathbf{0 5 5 7}\end{array}$ & -0387 & -0380 & $\begin{array}{r}-3.87 \\
\mathbf{0 5 8 1}\end{array}$ & $\begin{array}{r}-3.77 \\
0586\end{array}$ & & \\
\hline & $\begin{array}{r}5.42 \\
\end{array}$ & $\begin{array}{r}5.36 \\
\end{array}$ & -3.02 & -2.96 & $\begin{array}{r}-6.64 \\
\end{array}$ & 5.65 & & \\
\hline IM70_74 & $\begin{array}{r}.0913 \\
7.92\end{array}$ & $\begin{array}{r}.0931 \\
8.06\end{array}$ & * & * & & & & \\
\hline IM65_69 & .1124 & .1152 & .0320 & .0332 & & & & \\
\hline $\begin{array}{l}\text { IM96_00*FSUJ } \\
\text { EW }\end{array}$ & 8.17 & $\begin{array}{r}8.36 \\
-.0536\end{array}$ & 2.06 & 2.13 & & & & -.5034 \\
\hline & & -6.39 & & & & & & -4.47 \\
\hline $\begin{array}{l}\text { IM91_95*FSUJ } \\
\text { EW }\end{array}$ & & -.3033 & & & & & & -.3093 \\
\hline & & -3.97 & & & & & & -2.77 \\
\hline $\begin{array}{l}\text { IM87_90*FSUJ } \\
\text { EW }\end{array}$ & & -.1352 & & & & -.0598 & & -.1445 \\
\hline & & -1.60 & & & & -0.59 & & -1.23 \\
\hline $\begin{array}{l}\text { IM85_86*FSUJ } \\
\text { EW }\end{array}$ & & -.3156 & & & & -.2971 & & 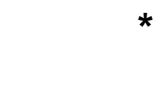 \\
\hline & & -1.73 & & & & -1.61 & & \\
\hline $\begin{array}{l}\text { IM75_79*FSUJ } \\
\text { EW }\end{array}$ & & -.0911 & & -.2556 & & -.0559 & & \\
\hline $\begin{array}{l}\text { IM70_74*FSUJ } \\
\text { EW }\end{array}$ & & $\begin{array}{r}-0.95 \\
-.0100\end{array}$ & & -1.49 & & -0.55 & & \\
\hline
\end{tabular}


IM65_69*FSUJ

EW

ENGSPK

MARRSP

RURAL

SOUTH

FSU

ASIA

LATAMER

CANADA

OTHER

FSU*EDUCYRS
$-0.06$

$-.1193$

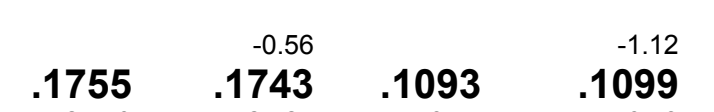

$\begin{array}{rrr}24.40 & 24.24 & 6.45 \\ .2022 & .2030 & .2582\end{array}$

33.38

$-.1159$

$-4.51$

$-.0386$

33.52

$-.1163$

$-4.53$

$-.0390$

20.31

$-.1154$

$-2.17$

$-.0600$

$-.1937$

$-.2899$

-4.69
.0500

.0500
0.82

$1559-.0490$

$-.1592$

$-15.35$

$-.3224$

$-31.39$

.1760

7.92

$-.2180$

$-13.14$

$-.14 .89$

$-.3216$

$-31.20$

.1778

8.00

$-.2159$

$-12.99$

.0256

5.41

$$
-2.62
$$

$-.2175$

$-.0165$

$-0.42$

$-.1333$

$-3.91$

79582
7827

.3652

.3652
.3650

\section{$-.2896$}

$$
-12.28
$$

\begin{tabular}{rrrrr}
-1.12 & & & & \\
.1099 & .1522 & .1525 & .1985 & .1967 \\
6.48 & 14.83 & 14.85 & 22.31 & 22.11 \\
.2580 & .2166 & .2166 & .1705 & .1714 \\
20.29 & 24.86 & 24.85 & 21.87 & 22.00 \\
-.1159 & -.1079 & -.1083 & -.1293 & -.1295 \\
-2.18 & -2.96 & -2.97 & -4.00 & -4.01 \\
-.0601 & -.0347 & -.0347 & -.0267 & -.0273 \\
-4.70 & -3.83 & -3.83 & -3.25 & -3.33 \\
-.1407 & -.0430 & -.1929 & -.2760 & -.3840 \\
-1.03 & -1.11 & -2.22 & -11.43 & -5.56 \\
-.0460 & -.1901 & -.1857 & -.2312 & -.2267 \\
-2.44 & -11.77 & -11.39 & -16.41 & -15.86 \\
-.2163 & -.3615 & -.3588 & -.3962 & -.3953 \\
-12.19 & -22.40 & -22.13 & -27.88 & -27.64 \\
-.0147 & .1239 & .1275 & .2851 & .2884 \\
-0.37 & 3.12 & 3.21 & 9.77 & 9.87 \\
-.1311 & -.2070 & -.2034 & -.2889 & -.2859 \\
-3.84 & -8.18 & -8.02 & -13.46 & -13.28 \\
. $\mathbf{0 3 0 1}$ & &. $\mathbf{0 1 5 7}$ & &. $\mathbf{0 2 9 6}$ \\
2.40 & & 2.26 & & 4.71 \\
22012 & 39079 & 39079 & 43967 & 43967 \\
.8134 & .7769 & .7769 & .7682 & .7677 \\
.3238 & .3216 & .3217 & .381 & .3789 \\
.3232 & .3213 & .3213 & .3779 & .3787 \\
\hline & & & &
\end{tabular}

ADJUSTED R2

Appendix Table B-2 Notes:

Estimated Coefficients in Bold. T-ratios below.

Includes only immigrants who worked and had non-zero earnings in 1999.

*omitted as benchmark; benchmark is 1980-1984 and EUROPE unless otherwise

noted.

Source: 2000 Census of Population, Public Use Microdata Sample, 5\% Sample

1990 Census of Population, Public Use Microdata Sample, 5\% Sample

1980 Census of Population, Public Use Sample, B and C Sample Files Combined, 2\%

Sample 
Appendix Table B-2A: Regression Analysis of Earnings Among Adult Males Who Immigrated Since 1965: 2000, 1990, 1980. Dependent Variable=LNEARN.

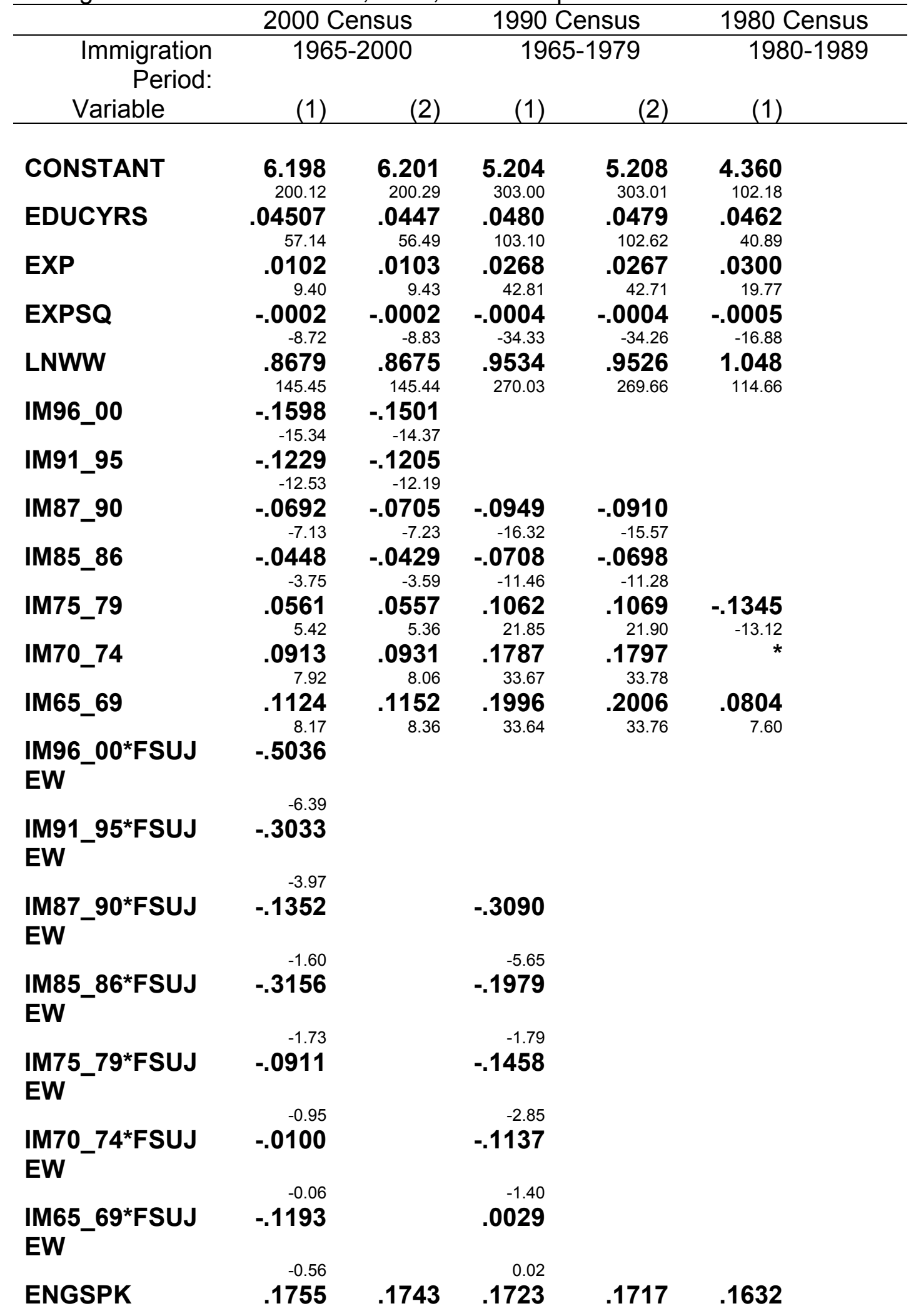




\begin{tabular}{|c|c|c|c|c|c|}
\hline & 24.40 & 24.24 & 39.38 & 39.25 & 14.84 \\
\hline MARRSP & .2022 & .2030 & .2093 & .2099 & .1718 \\
\hline RURAL & -.1159 & -.1163 & $\begin{array}{r}57.12 \\
-.0183\end{array}$ & $\begin{array}{r}57.26 \\
-.0186\end{array}$ & $\begin{array}{r}16.11 \\
-.0190\end{array}$ \\
\hline & -4.51 & -4.53 & -2.36 & -2.40 & -1.03 \\
\hline SOUTH & $\begin{array}{r}-.0386 \\
-6.13\end{array}$ & $\begin{array}{r}-.0389 \\
-6.19\end{array}$ & $\begin{array}{r}-.0925 \\
-23.52\end{array}$ & $\begin{array}{r}-.0925 \\
-23.51\end{array}$ & $\begin{array}{r}-.0312 \\
-2.97\end{array}$ \\
\hline FSU & $\begin{array}{r}-1937 \\
-9.11\end{array}$ & $\begin{array}{r}-2899 \\
-5.11\end{array}$ & $\begin{array}{r}-1759 \\
-9.36\end{array}$ & $\begin{array}{r}-.3021 \\
-3.42\end{array}$ & $\begin{array}{r}.0895 \\
-0.66\end{array}$ \\
\hline ASIA & $\begin{array}{r}-.1592 \\
-15.35\end{array}$ & $\begin{array}{r}-.1559 \\
-14.89\end{array}$ & $\begin{array}{r}-.1955 \\
-34.34\end{array}$ & $\begin{array}{r}-.1953 \\
-34.32\end{array}$ & $\begin{array}{r}-.1862 \\
-14.44\end{array}$ \\
\hline LATAMER & $\begin{array}{r}-.3224 \\
-31.39\end{array}$ & $\begin{array}{r}-.3216 \\
-31.20\end{array}$ & $\begin{array}{r}-.3227 \\
-57.83\end{array}$ & $\begin{array}{r}-.3231 \\
-57.90\end{array}$ & $\begin{array}{r}-.2612 \\
-21.63\end{array}$ \\
\hline CANADA & $\begin{array}{r}.1760 \\
7.92\end{array}$ & $\begin{array}{r}1777 \\
8.00\end{array}$ & $\begin{array}{r}.0936 \\
6.99\end{array}$ & $\begin{array}{r}.0937 \\
7.00\end{array}$ & $\begin{array}{r}.1375 \\
4.83\end{array}$ \\
\hline OTHER & -.2180 & -.2159 & -.2511 & -.2511 & -.2276 \\
\hline FSU*EDUCYRS & -13.14 & $\begin{array}{r}-12.99 \\
.0256 \\
5.41\end{array}$ & -32.60 & $\begin{array}{r}-32.60 \\
.0194 \\
3.79\end{array}$ & $\begin{array}{r}-13.03 \\
-.0280 \\
-3.08\end{array}$ \\
\hline $\begin{array}{r}\text { SAMPLE SIZE } \\
\text { STANDARD ERROR } \\
R 2 \\
\text { ADJUSTED R2 }\end{array}$ & $\begin{array}{l}79582 \\
.7830 \\
.3646 \\
.3645\end{array}$ & $\begin{array}{l}79582 \\
.7827 \\
.3652 \\
.3650\end{array}$ & $\begin{array}{r}202113 \\
.7456 \\
.4267 \\
.4266 \\
\end{array}$ & $\begin{array}{r}202113 \\
.7455 \\
.4268 \\
.4268 \\
\end{array}$ & $\begin{array}{l}35915 \\
.7898 \\
.3895 \\
.3892 \\
\end{array}$ \\
\hline
\end{tabular}

Table 6A Notes:

Coefficients in Bold. T-ratios below.

*omitted as benchmark; 1980-1984 and EUROPE are benchmarks unless otherwise noted.

Source: 2000 Census of Population, Public Use Microdata Sample, 5\% Sample 1990 Census of Population, Public Use Microdata Sample, 5\% Sample 1980 Census of Population, Public Use Sample, B and C Sample Files Combined, 2\% Sample 
Appendix Table B-3: Regression Analysis of Fluency In English Among Adult Soviet Jewish Males Who Immigrated Since 1965. Dependent Variable= ENGSPK

\begin{tabular}{|c|c|c|c|c|c|c|c|c|}
\hline \multirow{3}{*}{$\begin{array}{c}\text { Immigration } \\
\text { Period: } \\
\text { Variable }\end{array}$} & \multicolumn{6}{|c|}{2000 Census } & \multirow{2}{*}{\multicolumn{2}{|c|}{$1990-2000$}} \\
\hline & \multicolumn{2}{|c|}{$1965-2000$} & \multicolumn{2}{|c|}{ 1965-1979 } & \multicolumn{2}{|c|}{ 1980-1989 } & & \\
\hline & (1) & $(2)$ & (1) & (2) & (1) & $(2)$ & (1) & (2) \\
\hline CONSTANT & .8068 & .8426 & .6503 & .6503 & .7613 & .7743 & .7893 & .8469 \\
\hline & 11.18 & 11.46 & & 5.30 & 9.33 & 9.37 & 7.40 & 7.78 \\
\hline EDUCYRS & .0339 & .0327 & .0194 & .0187 & .0174 & .0166 & .0387 & .0370 \\
\hline & 11.28 & 10.75 & $\begin{array}{r}3.70 \\
\end{array}$ & 3.50 & 4.56 & $\begin{array}{r}4.30 \\
0\end{array}$ & 10.89 & 10.24 \\
\hline AGE & -.0078 & -.0079 & -.0008 & -.0010 & -.0016 & -.0016 & -.0101 & $\begin{array}{r}-.0101 \\
-825\end{array}$ \\
\hline IM96_00 & $\begin{array}{r}-7.63 \\
-.4482\end{array}$ & $\begin{array}{r}-7.61 \\
-.4393\end{array}$ & -0.42 & -0.54 & -1.28 & -1.27 & $\begin{array}{r}-8.23 \\
-.4194\end{array}$ & $\begin{array}{r}-8.25 \\
-.4165\end{array}$ \\
\hline & -10.36 & -10.13 & & & & & $\begin{array}{r}.47 \\
-4.89\end{array}$ & -4.87 \\
\hline IM91_95 & -.1873 & -.1820 & & & & & -.1544 & -.1555 \\
\hline & -4.49 & -4.34 & & & & & -1.82 & -1.83 \\
\hline IM87_90 & $\begin{array}{r}-.0759 \\
-1.69\end{array}$ & $\begin{array}{r}-.0702 \\
-1.56\end{array}$ & & & $\begin{array}{r}-.0381 \\
-1.16\end{array}$ & $\begin{array}{r}-.0359 \\
-1.07\end{array}$ & $\begin{array}{r}-.0385 \\
-0.44\end{array}$ & $\begin{array}{r}-.0389 \\
-0.45\end{array}$ \\
\hline IM85_86 & -.0404 & -.0341 & & & -.0405 & -.0393 & * & 0.74 \\
\hline & -0.46 & -0.39 & & & -0.69 & -0.67 & & \\
\hline IM75_79 & -.0078 & -.0019 & -.0026 & -.0001 & -.0210 & -.0193 & & \\
\hline & -0.16 & -0.04 & -0.05 & -0.02 & -0.64 & -0.58 & & \\
\hline IM70_74 & .0651 & .0643 & * & * & & & & \\
\hline & & 0.81 & & & & & & \\
\hline IM65_69 & .1215 & .1344 & .0778 & .0814 & & & & \\
\hline MARRSP & 1.20 & 1.33 & 1.01 & 1.02 & & & & \\
\hline MARRSP & -.0047 & -.0071 & .0296 & .0323 & .0239 & .0225 & -.0049 & -.0095 \\
\hline & -0.18 & -0.27 & 0.52 & 0.56 & 0.68 & 0.63 & -0.16 & -0.31 \\
\hline RURAL & .1702 & .1939 & .0346 & .0265 & .0644 & .0776 & .2068 & .2317 \\
\hline & 1.41 & 1.60 & 0.20 & 0.15 & 0.38 & 0.46 & 1.43 & 1.60 \\
\hline SOUTH & .0743 & .0755 & .0396 & .0317 & .0511 & .0464 & .0823 & .0840 \\
\hline & 2.49 & 2.52 & 0.60 & 0.47 & 1.19 & 1.07 & 2.39 & 2.44 \\
\hline CHILD & -.0261 & -.0249 & .0156 & .0108 & -.0259 & -.0252 & -.0275 & -.0257 \\
\hline & -1.17 & -1.11 & 0.37 & & -0.89 & -0.87 & -1.05 & \\
\hline UKRAINE & & -.0609 & & .0641 & & -.0288 & & -.0695 \\
\hline & & -2.45 & & 0.70 & & -0.89 & & -2.43 \\
\hline RELIG & & .0061 & & .0524 & & .0374 & & -.0064 \\
\hline & & 0.19 & & 0.90 & & 0.93 & & -0.17 \\
\hline OTHANCS & & -.0427 & & .0276 & & .0006 & & -.0533 \\
\hline & & -1.69 & & 0.55 & & -0.02 & & -1.78 \\
\hline SAMPLE SIZE & 1460 & 14 & 17 & 1 & 385 & 38 & 1196 & 1196 \\
\hline STANDARD ERROR & .3603 & .3598 & .2359 & .2373 & .2361 & .2364 & .3811 & .3804 \\
\hline R2 & .2270 & .2308 & .1038 & .1099 & .0685 & .0740 & .2280 & .2276 \\
\hline ADJUSTED R2 & .2200 & .2223 & .0606 & .0498 & .0462 & .0442 & .2169 & .2198 \\
\hline
\end{tabular}

Coefficient Estimates in bold. T-ratios below.

*omitted as benchmark; 1980-1984 is benchmark unless otherwise noted.

Source: 2000 Census of Population, Public Use Microdata Sample, 5\% Sample. 
Appendix Table B-4: Regression Analysis of Earnings Among Adult Soviet Jewish Males Who Immigrated Since 1965

Dependent Variable $=$ LNEARN

\begin{tabular}{|c|c|c|c|c|c|c|c|c|}
\hline \multirow{3}{*}{$\begin{array}{c}\text { Immigration } \\
\text { Period: } \\
\text { Variable }\end{array}$} & \multicolumn{6}{|c|}{2000 Census } & \multirow{2}{*}{\multicolumn{2}{|c|}{$1990-2000$}} \\
\hline & \multicolumn{2}{|c|}{$1965-2000$} & \multicolumn{2}{|c|}{$1965-1979$} & \multicolumn{2}{|c|}{$1980-1989$} & & \\
\hline & (1) & (2) & (1) & (2) & (1) & (2) & (1) & (2) \\
\hline CONSTANT & 4.536 & 4.502 & 5.394 & 5.516 & 4.202 & 4.330 & 4.429 & 4.353 \\
\hline & 18.90 & 18.51 & 5.28 & 5.45 & 6.59 & 6.75 & 15.02 & 14.52 \\
\hline EDUCYRS & .0799 & .0807 & .0944 & .0889 & .0980 & .0985 & .0729 & .0749 \\
\hline & 11.53 & 11.52 & 4.60 & 4.33 & 6.43 & 6.42 & 9.49 & 9.59 \\
\hline EXP & .0079 & .0069 & .0363 & .0417 & .0333 & .0349 & .0013 & .0001 \\
\hline & & & & 1.81 & 1.97 & 2.06 & 0.14 & -0.01 \\
\hline EXPSQ & -.0002 & -.0001 & -.0008 & -.0009 & -.0006 & -.0006 & -.00002 & -.00001 \\
\hline & -0.93 & -0.82 & -1.89 & -2.11 & -1.69 & -1.83 & -0.14 & -0.01 \\
\hline LNWW & 1.174 & 1.174 & .9325 & .9183 & 1.065 & 1.016 & 1.199 & 1.203 \\
\hline & 23.81 & 23.81 & 3.56 & 3.52 & 7.08 & 6.71 & 22.96 & 23.00 \\
\hline IM96_00 & -.4377 & -.4337 & & & & & -.2328 & -.2295 \\
\hline & -4.48 & -4.43 & & & & & -1.30 & -1.28 \\
\hline IM91_95 & -.2595 & -.2491 & & & & & -.0548 & -.0432 \\
\hline & -2.84 & -2.71 & & & & & -0.31 & -0.25 \\
\hline IM87 90 & -.0658 & -.0547 & & & -.0118 & .0326 & .1384 & .1483 \\
\hline & -0.67 & -0.56 & & & -0.10 & 0.27 & 0.77 & 0.83 \\
\hline IM85_86 & $\begin{array}{r}-1959 \\
-1.02\end{array}$ & $\begin{array}{r}-.1963 \\
-1.02\end{array}$ & & & $\begin{array}{r}-.1640 \\
-0.77\end{array}$ & $\begin{array}{r}-.1539 \\
-0.72\end{array}$ & * & t \\
\hline IM75_79 & .1217 & .1346 & -.1757 & -1092 & .1359 & .1868 & & \\
\hline & 1.12 & 1.23 & -0.98 & -0.60 & 1.12 & 1.51 & & \\
\hline IM70_74 & .2673 & .2608 & * & * & & & & \\
\hline & 1.53 & 1.49 & & & & & & \\
\hline IM65_69 & .1444 & .1057 & -.0816 & -.0242 & & & & \\
\hline & 0.65 & 0.48 & -0.31 & -0.09 & & & & \\
\hline ENGSPK & .2287 & .2297 & -.1009 & -.0724 & .2661 & .2571 & .2489 & .2526 \\
\hline & 3.94 & 3.96 & -0.37 & -0.26 & 1.41 & 1.37 & 4.11 & 4.17 \\
\hline MARRSP & .0697 & .0794 & .3685 & .3328 & .2069 & .2354 & .0247 & .0378 \\
\hline & 1.38 & 1.57 & 2.13 & 1.93 & 1.81 & 2.05 & 0.45 & 0.68 \\
\hline RURAL & -.3636 & -.3703 & -.8184 & -.6532 & -.8542 & -.8907 & -.2530 & -.2655 \\
\hline & -1.38 & -1.40 & -1.42 & -1.14 & -1.39 & -1.45 & -0.84 & -0.89 \\
\hline SOUTH & -.0619 & -.0732 & .2152 & 1913 & -.0523 & -.0581 & -.0779 & -.0921 \\
\hline & -0.95 & -1.12 & 0.94 & 0.84 & -0.33 & -0.37 & -1.09 & -1.29 \\
\hline UKRAINE & & -.0268 & & -.03869 & & -.1493 & & .0034 \\
\hline & & -0.49 & & -2.35 & & -1.26 & & 0.06 \\
\hline RELIG & & .0143 & & .0827 & & -.0394 & & -.0119 \\
\hline & & 0.20 & & 0.42 & & -0.27 & & -0.15 \\
\hline OTHANCS & & .1126 & & -.1302 & & 1792 & & .1268 \\
\hline & & 2.03 & & -0.78 & & 1.48 & & 2.03 \\
\hline SAMPLE SIZ & 1460 & 14 & 174 & 17 & 385 & 385 & 1196 & 1196 \\
\hline STANDARD ERROR & .7867 & .78 & .8035 & .79 & .8612 & .85 & .7877 & .7871 \\
\hline $\mathrm{R} 2$ & .4307 & .4329 & .3246 & .352 & .2801 & 2902 & .4323 & 4346 \\
\hline ADJUSTED R2 & .4248 & .4258 & .2834 & .3000 & 32589 & .2634 & .4270 & .4279 \\
\hline
\end{tabular}

Estimated Coefficients in bold. T-ratios below.

Includes only immigrants who worked and had non-zero earnings in 1999.

Source: 2000 Census of Population, Public Use Microdata Sample, 5\% Sample. 